\title{
Production of Peanut Intercropped with Forage Palm in Pernambuco State, Brazil
}

\author{
Juliana Aparecida Santos Andrade, Jeandson Silva Viana*, \\ José Jairo Florentino Cordeiro Junior, Abraão Cicero da Silva, \\ Edilma Pereira Gonçalves, Djayran Sobral Costa \\ Academic Unit Garanhuns, Federal Rural University of Pernambuco, Recife, Brazil \\ Email: ${ }^{*}$ jeandson@uag.ufrpe.br
}

Received 1 November 2014; accepted 6 April 2015; published 10 April 2015

Copyright (C) 2015 by authors and Scientific Research Publishing Inc.

This work is licensed under the Creative Commons Attribution International License (CC BY). http://creativecommons.org/licenses/by/4.0/

(c) (i) Open Access

\begin{abstract}
The greater use of crop fields by increasing plant population is an alternative to minimize losses to the farmers who use crop intercropped provides other benefits such as lower incidence of diseases and pests, and better exploitation and enrichment agroecosystem. The objective of this study was to evaluate the effect of the population of peanuts with and without inoculation and intercropping with forage palm on growth, productivity and biomass peanut. The treatments consisted of different populations of peanut (one, two and three rows of peanut row spacing of two meters of cactus pear), with and without inoculant, analyzed in subdivided plot scheme $(3 \times 2)$, totalizing six treatments in a randomized block design with four replications. The variables evaluated were plant height, number of branches, shoot dry mass and root nodule number, nodule dry weight, biomass productivity and legumes. The largest population of plants in number of lines of peanut intercropped with forage cactus promotes greater total biomass production and yield of beans and does not alter the height, branch number, dry mass of aerial part roots and nodules. The inoculant application did not result in to increased productivity biomass and growth of peanut plants, their use is not indicated. The planting of a row of peanuts between the rows of palm is not economically recommended.
\end{abstract}

\section{Keywords}

Arachis hypogaea L., Inoculation, Population, Nopalea cochenillifera

\section{Introduction}

The cultivation of peanut (Arachis hypogaea L.) occurs in over 90 countries in the two hemispheres, particularly

*Corresponding author.

How to cite this paper: Andrade, J.A.S., Viana, J.S., Cordeiro Junior, J.J.F., da Silva, A.C., Gonçalves, E.P. and Costa, D.S. (2015) Production of Peanut Intercropped with Forage Palm in Pernambuco State, Brazil. American Journal of Plant Sciences, 6, 818-825. http://dx.doi.org/10.4236/ajps.2015.66088 
in tropical regions in the range of between $30^{\circ}$ latitude north and south. In Brazil the peanut is grown more significantly in ten states, with the largest national producer São Paulo, followed by Bahia and Mato Grosso [1]. It is a culture perfectly adapted to agriculture family, predominantly in the semiarid region, being simple burndown methods and good productivity even without the intensive use of inputs [2].

The forage palm (Nopalea cochenillifera Salm-Dyck), by containing on average $90 \%$ water in its constitution, contributes to meet the demand of this valuable liquid during periods of prolonged droughts, being provided as green food and mixed with other foods from the herd. The Northeast region of Brazil along with the states of Goiás, Mato Grosso and Minas Gerais currently represent a production in planted area of 500,000 hectares of Opuntia ficus indica species, with cultivars Gigante and Round and Nopalea cochenillifera Salm-Dyck species, cultivars miúda or doce [3] [4]. According Oliveira et al. (2011) [4] a farm livestock in northeastern Brazil is affected by the variability of the distribution of rains, due affect forage production. With this, the forage cactus is an important forage resource in periods of drought, due to its high potential for biomass production in semiarid conditions.

Intercropping is a practical commonly used by small producer in Brazilian Northeast, a practice that consists in simultaneous cultivation of two cultures, and the spatial and temporal dimension of coexistence between cultivated plants. This cultivation has advantages, such as reduced soil erosion, reduced incidence of weeds, pests and increased income of small producer due to diversification of agricultural crops in the same area [5]. That way, the intercrop is a highly viable alternative and great expression for subsistence agriculture, since it occurs in the same area, so that one of the cultures to coexist with the other, in all or at least part of their cycle [6].

Intercropping forage palm with some crops such as peanuts, beans, corn, among other crops, can be an alternative to the better utilization of the area and land cover. Contributing to food and income, thus becoming an important option in family agriculture. That way, the forage will be used in animal feed and peanuts can be used both in animal feed and human [7]. The presence of on peanut crop interspersed between lines favors weed control, mainly by land use, and economic benefits by optimizing the use of soil and nitrogen fixation, yield two crops simultaneously [8].

The culture of peanuts can benefit the introduction of specific bacteria growth promoters which can meet the need of nutrients required for the crop species like nitrogen in the case of bacteria that carry out biological fixation. Inoculation with Rhizobium bacteria group is a practice that provides agronomic benefits and inoculation with selected strains that are able to increase the effectiveness of the symbiosis and crop production [9].

The search for alternative systems for better utilization of soil and climatic conditions and the increase in crop productivity on small rural properties is extremely important, but are scarce in the literature concerning the research intercropping between forage palm and peanuts. Given the above, the objective of this study was to evaluate the effect of populations of peanuts with and without inoculation and intercropping with forage cactus on growth, productivity and biomass peanut.

\section{Material and Methods}

The experiment was conducted under field conditions, in the municipality of Paranatama-PE, Meridional Agreste with geographical coordinates of $08^{\circ} 53^{\prime} 19^{\prime \prime}$ south latitude and $36^{\circ} 37^{\prime} 34^{\prime \prime}$ west longitude. The climate is As', equivalent to a hot and humid climate, according to Köeppen classification [10], with an altitude of $879 \mathrm{~m}$ soil classified as Argisoil [11]. Soil testing showed pH 5.9, $18 \mathrm{mg} \cdot \mathrm{P} \cdot \mathrm{dm}^{-3}, \mathrm{~K}, \mathrm{Ca}, \mathrm{Mg}$, $\mathrm{Na}$ and $\mathrm{Al}$ of 0.19, 2.10, 1.50, 0.06 and $0.00 \mathrm{dm} \cdot \mathrm{cmolc}^{-3}$, respectively. The physical analysis of the soil had as most significant results of the sand and silte + clay, with values of $58.9 \%$ and $40 \%$, respectively, being classified as arene clayey texture. The pluvial precipitation for the period of conduction of the experiment was $29.25 \mathrm{~mm}$ and maximum temperature of $30.8^{\circ} \mathrm{C}$ and minimum $24.8^{\circ} \mathrm{C}$. Evaluations of plant height and number of branches were conducted in the experimental conditions, and CENLAG (Center Laboratory of Garanhuns), located in the Academic Unit of Garanhuns-Federal Rural University of Pernambuco (UAG/UFRPE), were carried out mass shoot dry matter, root dry mass, number and weight of nodules and productivity of biomass and grain. The peanut crop (cultivar BR1) was evaluated in a intercropping with forage cactus Nopalea cochenillifera Salm-Dyck, petite variety, with spacing of $2 \mathrm{~m}$ between lines and $0.2 \mathrm{~m}$ between plants, with depth of $15 \mathrm{~cm}$ and fertilized with $10 \mathrm{t} \cdot \mathrm{ha}^{-1}$ of hardened bovine manure [12]. Intercropping peanut occurred in different populations (one, two and three rows peanut spacing between lines of forage cactus), with and without legume inoculation with bacteria belonging to the Bradyrhizobium sp. (6144 SEMIA of Biomax ${ }^{\circledR}$ Premium Peat-Peanut), at a dose of $100 \mathrm{~g} / 40 \mathrm{~kg}$ of seeds, 
sowing was 18 seeds per $\mathrm{m}$ [13]. The sowing of groundnut experimental area received $277 \mathrm{~kg} \cdot \mathrm{ha}^{-1}$ of superphosphate $\left(\mathrm{P}_{2} \mathrm{O}_{5}\right)$ and $25 \mathrm{~kg} \cdot \mathrm{ha}^{-1}$ of potassium chloride $\left(\mathrm{K}_{2} \mathrm{O}\right)$, respectively.

The experiment was analyzed in subdivided plot scheme $(3 \times 2)$ with the experimental area of $120 \mathrm{~m}^{2}$, comprising 12 plots ( 3 populations $\times 4$ blocs), and each plot was divided into two subplots (with and without inoculation) totaling 24 plots, with useful area of $1 \mathrm{~m}^{2}$.

The treatments composed of one row $\left(90,000\right.$ plants $\left.\cdot \mathrm{ha}^{-1}\right)$ with and without inoculation, groundnut was sown in single row, distant line of forage cactus $1 \mathrm{~m}$. The set distance between the rows of peanuts with two treatments $\left(180,000\right.$ plants $\left.\cdot \mathrm{ha}^{-1}\right)$ and three rows $\left(270,000\right.$ plants $\left.\cdot \mathrm{ha}^{-1}\right)$ was $0.5 \mathrm{~m}$, for treatments with two lines with and without inoculation spacing between rows of peanuts compared to the cactus pear was $0.75 \mathrm{~m}$, while the treatments three peanut lines between the lines forage cactus, the distance was $0.50 \mathrm{~m}$.

For the evaluations were randomly selected 10 plants in the usable area. The height of the peanut plants was measured with a graduated ruler, and the number of branches was recorded during the harvest of the crop, by counting the number of ramifications. For dry weight of shoot and root plants were sectioned into shoots and roots and put into bags and left to air circulation oven at $60^{\circ} \mathrm{C}$ for 72 hours. After this period the samples were weighed and the results were expressed in grams. The determination of the number of nodules in the roots was carried out by counting. The nodules were weighed and placed to dry in an oven at $60^{\circ} \mathrm{C}$ to determine the dry weight of the nodules. Biomass production of peanut was obtained by weighing all plants, including pods, and transformed to $\mathrm{kg} \cdot \mathrm{ha}^{-1}$. The groundnut productivity was obtained from the values found for the pods in the usable area, and the results converted to $\mathrm{kg} \cdot \mathrm{ha}^{-1}$. The average data were subjected to analysis of variance and treatment means were compared by Tukey test at 5\% probability, with the aid of software SISVAR [14].

\section{Results and Discussion}

According to the results of the experiment Table 1, different populations and inoculation didn't interfere plant height. The density lines between peanut seems not to print stresses on plant growth, since for this variable was not observed significant effect. Choice of the best arrangement and sowing dates is crucial in the performance of the system, in other words, the maximization of production [15]. This way can be argued in this paper that the plants grown at different densities between the lines, its height wasn't increased with the competition between the rows of peanut plants. Genotypes upright (as cultivating BR1) are often grown with high populations because they use less area to fruit development in relation to material type prostrate [16]. Silveira (2010) [17] verified that lower plant height in the peanut crop, corresponded to the lowest planting density of 13 plants per $\mathrm{m}^{2}$.

Regarding the number of ramifications peanut (Table 1) it did not occur significant effects for treatments when evaluated population and inoculation. These results contribute to the choice of planting system of higher population of peanut plants (three lines) one plants showed a number of similar ramifications, that is, the greatest number of plants per area, and in competition with the forage palm not reduced ramifications, which allows greater biomass and productivity by area. The results found in this study are different from Silva e Beltrão (2000) [18], working with different populations peanut, concluded that at higher densities there was less number of ramifications per plant.

According to mean values of Table 1, there wasn't difference for the interaction for shoot dry mass of peanut plants. Even with the increase of population, there weren't significant differences in shoot dry mass of individual plants. The effect of inoculation on shoot dry mass showed no significant increase in the plant demonstrating high ability of rhizobia on the self-production of nitrogen. This information is consistent with Santos et al. (2005) [19], who concluded that the peanut crop, the rhizobia provided good nodulation, with an increase in total accumulated $\mathrm{N}$ and dry matter yield of the shoots.

The root dry weight of peanut plants was not influenced by the presence or absence of inoculant and there was no difference between treatments with different spacings peanut intercropping with the palm (Table 1), inferring that this competition didn't bring damage to development of the roots, so one should opt for planting system with the largest population, which will provide greater protection to the soil preventing its degradation.

In the evaluation of the average weight of nodules (Table 2), one realizes that no significant interaction between treatments. These results show that may exist in the soil bacteria capable of colonizing the roots of legumes. Castro et al. (2005) [20] found no significant results for the dry weight of nodules between treatments with and without inoculation of peanuts. Borges et al. (2007) [9] reported that the peanut is a species that can establish symbiotic associations with native strains of rhizobia and benefit from this interaction under low $\mathrm{N}$ 
Table 1. Plant height, number of ramifications, dry mass of aerial part and roots of peanut plants under different planting populations with and without inoculation in intercropping with forage. UAG/UFRPE, Garanhuns, 2012.

\begin{tabular}{|c|c|c|}
\hline & \multicolumn{2}{|c|}{ Height } \\
\hline & With inoculation & Without inoculation \\
\hline \multicolumn{3}{|l|}{ Populations (plants $\cdot \mathrm{ha}^{-1}$ ) } \\
\hline $1(90,000)$ & $27.67 \mathrm{aA}$ & $26.25 \mathrm{aA}$ \\
\hline $2(180,000)$ & $22.40 \mathrm{aA}$ & $24.30 \mathrm{aA}$ \\
\hline $3(270,000)$ & $25.02 \mathrm{aA}$ & $24.05 \mathrm{aA}$ \\
\hline CV\% (Populations) & 13.49 & \\
\hline \multirow[t]{3}{*}{ CV\% (Inoculation) } & 14.38 & \\
\hline & \multicolumn{2}{|c|}{ Number of ramifications } \\
\hline & With inoculation & Without inoculation \\
\hline \multicolumn{3}{|l|}{ Populations (plants $\cdot$ ha $^{-1}$ ) } \\
\hline $1(90,000)$ & $7.05 \mathrm{aA}$ & $6.50 \mathrm{aA}$ \\
\hline $2(180,000)$ & $7.20 \mathrm{aA}$ & $6.57 \mathrm{aA}$ \\
\hline $3(270,000)$ & $6.77 \mathrm{aA}$ & $6.87 \mathrm{aA}$ \\
\hline CV\% (Populations) & 14.03 & \\
\hline CV\% (Inoculation) & 7.59 & \\
\hline
\end{tabular}

\begin{tabular}{|c|c|c|}
\hline & \multicolumn{2}{|c|}{ Dry mass of aerial part } \\
\hline & With inoculation & Without inoculation \\
\hline \multicolumn{3}{|l|}{ Populations (plants $\cdot \mathrm{ha}^{-1}$ ) } \\
\hline $1(90,000)$ & $40.00 \mathrm{aA}$ & $42.00 \mathrm{aA}$ \\
\hline $2(180,000)$ & $47.50 \mathrm{aA}$ & $41.00 \mathrm{aA}$ \\
\hline $3(270,000)$ & $23.00 \mathrm{aA}$ & $72.00 \mathrm{aA}$ \\
\hline CV\% (Populations) & 29.15 & \\
\hline CV\% (Inoculation) & 25.97 & \\
\hline
\end{tabular}

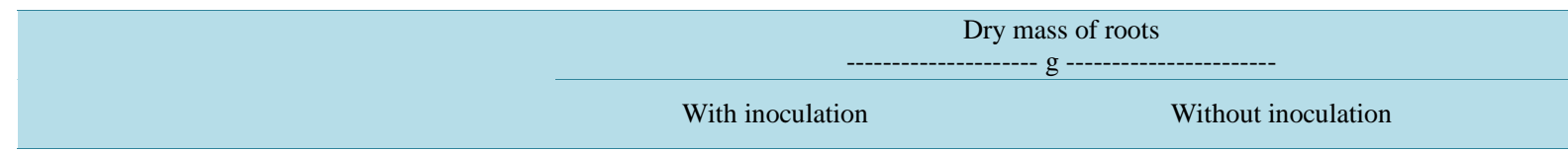

Populations (plants·ha ${ }^{-1}$ )

$\begin{array}{ccc}1(90,000) & 56.75 \mathrm{aA} & 82.00 \mathrm{aA} \\ 2(180,000) & 35.00 \mathrm{aA} & 51.00 \mathrm{aA} \\ 3(270,000) & 48.50 \mathrm{aA} & 23.00 \mathrm{aA} \\ \text { CV\% (Populations) } & 31.29 & \\ \text { CV\% (Inoculation) } & 40.61 & \end{array}$

Means followed by the same lowercase and uppercase in the column on the line do not differ significantly at the 0.05 level according to Tukey's test. 
Table 2. Weight and number of nodules, biomass productivity total and productivity of pods under different planting populations with and without inoculation in intercropping with forage. UAG / UFRPE, Garanhuns, 2012.

\begin{tabular}{|c|c|c|}
\hline & \multicolumn{2}{|c|}{ Weight of nodules } \\
\hline & With inoculation & Without inoculation \\
\hline \multicolumn{3}{|l|}{ Populations (plants $\cdot \mathrm{ha}^{-1}$ ) } \\
\hline $1(90,000)$ & $0.629 \mathrm{aA}$ & $0.459 \mathrm{aA}$ \\
\hline $2(180,000)$ & $0.641 \mathrm{aA}$ & $0.655 \mathrm{aA}$ \\
\hline $3(270,000)$ & $0.448 \mathrm{aA}$ & $0.514 \mathrm{aA}$ \\
\hline CV\% (Populations) & 31.29 & \\
\hline \multirow[t]{3}{*}{ CV\% (Inoculation) } & 40.61 & \\
\hline & \multicolumn{2}{|c|}{ Number of nodules } \\
\hline & With inoculation & Without inoculation \\
\hline \multicolumn{3}{|l|}{ Populations (plants·ha ${ }^{-1}$ ) } \\
\hline $1(90,000)$ & $507.00 \mathrm{bA}$ & $538.75 \mathrm{aA}$ \\
\hline $2(180,000)$ & $974.50 \mathrm{aA}$ & $658.25 \mathrm{aA}$ \\
\hline $3(270,000)$ & $616.00 \mathrm{abA}$ & $501.75 \mathrm{aA}$ \\
\hline CV\% (Populations) & 30.82 & \\
\hline \multirow[t]{3}{*}{ CV\% (Inoculation) } & 40.13 & \\
\hline & \multicolumn{2}{|c|}{ Biomass productivity } \\
\hline & With inoculation & Without inoculation \\
\hline \multicolumn{3}{|l|}{ Populations (plants·ha ${ }^{-1}$ ) } \\
\hline $1(90,000)$ & 2652 aA & $1908 \mathrm{bB}$ \\
\hline $2(180,000)$ & $2850 \mathrm{aA}$ & 3403 aA \\
\hline $3(270,000)$ & 3643 aA & 4215 aA \\
\hline CV\% (Populations) & 21.79 & \\
\hline \multirow[t]{3}{*}{ CV\% (Inoculation) } & 11.94 & \\
\hline & \multicolumn{2}{|c|}{ Productivity of pods } \\
\hline & With inoculation & Without inoculation \\
\hline \multicolumn{3}{|l|}{ Populations (plants $\cdot \mathrm{ha}^{-1}$ ) } \\
\hline $1(90,000)$ & $695.00 \mathrm{bA}$ & $630.00 \mathrm{bA}$ \\
\hline $2(180,000)$ & $881.00 \mathrm{abA}$ & $890.00 \mathrm{bA}$ \\
\hline $3(270,000)$ & $1149.00 \mathrm{aB}$ & $1736.00 \mathrm{aA}$ \\
\hline CV\% (Populations) & 24.17 & \\
\hline CV\% (Inoculation) & 21.86 & \\
\hline
\end{tabular}

Means followed by the same lowercase and uppercase in the column on the line do not differ significantly at the 0.05 level according to Tukey's test. 
availability in the soil, since the peanut is a species with the center of origin in Brazil [21] and tested cultivar (BR1) is indicated for the state of Pernambuco [13].

For the number of nodules per plant (Table 2) a significant difference only between the population of inoculated plants in cultivation, on which it was found that the population with two peanut lines between the spacing of forage palm showed the highest number of nodules, along with peanut plants were grown in three rows. Bolonhezi et al. (2005) [22] report that for being a legume, the peanut plant fixed amounts of sufficient nitrogen through symbiotic association with bacteria of the genus Bradyirhizobium sp., belonging to the group called "caupi miscellany". Montans et al. (2008) [23] concluded that the application of inoculant increased the number of nodules and when possible local populations are present, didn't observe the effect of inoculant, collaborating with what was observed in this study.

For biomass avaliation, as can be seen in Table 2, there was significant interaction between treatments, and realizes that the population formed with one row spacing between the cactus palm showed higher biomass production as a function of inoculant application. For other populations of peanut plants the presence or absence of inoculum didn't cause any effect. In the system of planting peanut that was not inoculated, the two highest yields were obtained when the peanut was grown with three or two lines, which did not differ, with values of 4215 and $3403 \mathrm{~kg} \cdot \mathrm{ha}^{-1}$, respectively. The practice of intercropping of different cultures produces significant amount of biomass, which is considered an alternative to the use of crop residues in feeding from the herd of small family producer, in the dry season. In this context the intercropping peanut with other species is an important alternative for the production of biomass, which can be important in supplementing animal feed in the period of scarcity of fodder and also provide plant cover.

For the production of pods (Table 2) showed a significant interaction between treatments (inoculation and plant population) and the highest result was observed with the planting of peanuts on a larger number of lines without inoculation reaching a productivity of $1736 \mathrm{~kg} \cdot \mathrm{ha}^{-1}$, differing planting one and two rows. In the populations inoculated with the largest population $\left(270,000\right.$ plants $\left.\cdot \mathrm{ha}^{-1}\right)$ higher yields $\left(1149 \mathrm{~kg} \cdot \mathrm{ha}^{-1}\right)$, with no difference achieved with the cultivation of peanuts in population formed with two lines $\left(180,000\right.$ plants $\left.\cdot \mathrm{ha}^{-1}\right)$ with inoculation. According to the Conab (2012) [1], crop productivity of peanut Brazil estimated for 2012 is 2,926 $\mathrm{kg} \cdot \mathrm{ha}^{-1}$ and the Northeast of Brasilian is $1287 \mathrm{~kg} \cdot \mathrm{ha}^{-1}$. Thus, considering that the cultivation of peanut was conducted in a intercropping, the results obtained with the peanut plant population demonstrate a greater positive effect on the productivity of the system of peanuts. In a general way, increasing the population of peanut between the lines forage cactus more positively contributed to the increase of biomass and does not affect the height, ramifications, enabling gains with the choice of planting system with increased productivity. Soares et al. (2011) [24] evaluating the intercropping of spacing cassava and peanut indicated in the system to be very advantageous not to cause significant damage, in terms of productivity of crops.

\section{Conclusions}

The largest number of rows peanut intercropped with forage palm promotes greater production of biomass and snap bean yield and does not alter the height, number of branches, shoot dry mass, and root nodules of the peanut plant.

The inoculant application did not lead to increased production of pods, biomass and growth of peanuts, it is not recommended its use.

The planting of a row of peanut between the rows of palm is not recommended.

\section{Acknowledgements}

Banco do Nordeste (BNB) for financing the study; BIOSOJA for donation inoculant; CAPES and CNPq for the scholarship of masters and undergraduate.

\section{References}

[1] Companhia Nacional de Abastecimento_-Conab (2012). http://www.conab.gov.br/OlalaCMS/uploads/arquivos/120510084952boletimmaio2012.pdf

[2] Beltrão, N.E. de M., de Oliveira, M.I.P., de Sousa Júnior, S.P., de Brito, G.G. and Cardoso, G.D. (2011) Ecofisiologia do algodoeiro (Gossypium hirsutum L. r. latifolium Hutch.). In: Beltrão, N.E. de M. and de Oliveira, M.I.P., Eds., Ecofisiologia das culturas de algodão, amendoim, gergelim, mamona, pinhão-manso e sisal, Embrapa Informação 
Tecnológica, Brasília, Campina Grande: Embrapa Algodão, 65-123.

[3] Oliveira Junior, S., Barreiros-Neto, M., Ramos, J.P. de F., Leite, M.L. de V., Brito, V.A. de V. and do Nascimento, J.P. (2009) Crescimento vegetativo da palma forrageira (Opuntia fícus-indica) em função do espaçamento no Semiárido Paraibano. Tecnologia \& Ciência Agropecuária, 3, 7-12. http://www.emepa.org.br/revista/volumes/tca v3 n1 fev/tca02 palma.pdf

[4] Oliveira, A.S.C., Cavalcante-Filho, F.N., Rangel, A.H.N. and Lopes, K.B.P. (2011) A Palma Forrageira: Alternativa para o semi-árido. Revista Verde, 6, 49-58. http://www.gvaa.com.br/revista/index.php/RVADS/article/viewFile/505/pdf 228

[5] Pinto, C. de M., Pitombeira, J.B., Souza, A. dos S., Neto, F. das C.V., Francisco, J.A.F., Távora, F.J.A. and Bezerra, A.M.E. (2013) Configuração de fileira no consórcio mamona x girassol: Produtividade e seus componentes. Revista Brasileira de Ciências Agrárias, 8, 33-41. http://agraria.pro.br/sistema/index.php?journal=agraria\&page=article\&op=view\&path\%5B\%5D=agraria_v8i1a1905\&p ath $\% 5 \mathrm{~B} \% 5 \mathrm{D}=1326$

[6] Costa, D.S. (2010) Sistemas de produção e cultivares de feijoeiro em consórcio com milho. Scientia Agraria, 11, 425430. http://ojs.c3sl.ufpr.br/ojs2/index.php/agraria/article/download/20387/13567 http://dx.doi.org/10.5380/rsa.v11i6.20387

[7] Ferreira, M.A., Silva, F.M., Bispo, S.V. and Azevedo, M. (2009) Estratégias na suplementação de vacas leiteiras no semiárido do Brasil. Revista Brasileira de Zootecnia, 38, 322-329. http://www.scielo.br/pdf/rbz/v38nspe/v38nspea32.pd

[8] Kasai, F.S. and Deuber, R. (2011) Manejo de plantas daninhas na cultura do amendoim. Boletim Técnico IAC, 207.

[9] Borges, W.L., Silva, C.E. de R., Xavier, G.R. and Rumjanek, N.G. (2007) Nodulação e fixação biológica de nitrogênio de acessos de amendoim com estirpes nativas de rizóbios. Revista Brasileira de Ciências Agrárias, 2, 32-37. http://www.redalyc.org/pdf/1190/119017336006.pdf

[10] Mota, F.S. and Agendes, M.O.O. (1986) Clima e agricultura no Brasil. Sagra, Porto Alegre.

[11] Biondi, C.M. (2010) Teores naturais de metais pesados nos solos de referência do estado de Pernambuco. Tese, Universidade Federal Rural de Pernambuco, Recife.

[12] Farias, I., De Andrade Lira, M., dos Santos, D.C., Tavares-Filho, J.J., dos Santos, M.V.F., Fernandes, A.P.M. and dos Santos, V.F. (2000) Manejo de colheita e espaçamento da palma forrageira, em consórcio com sorgo granífero no Agreste de Pernambuco. Pesquisa Agropecuária Brasileira, 35, 341-347. http://www.scielo.br/pdf/pab/v35n2/6880.pdf http://dx.doi.org/10.1590/S0100-204X2000000200013

[13] Santos, R.C. and Suassuna, T.M.F. (2006) Cultivo do amendoim: Cultivares. EMBRAPA, Sistema de Produção, 7.

[14] Ferreira, D.F. (1998) Sisvar-Sistema de análise de variância para dados balanceados. Lavras.

[15] Flesch, R.D. (2002) Efeitos temporais e espaciais no consórcio intercalar de milho e feijão. Pesquisa Agropecuária Brasileira, 37, 51-56. http://www.scielo.br/pdf/pab/v37n1/7547.pdf http://dx.doi.org/10.1590/S0100-204X2002000100007

[16] Cox, F.R. and Reid, P.H. (1965) Interaction of Plant Population Factors and Level of Production on the Yield and Grade of Peanuts. Agronomy Journal, 57, 455-456. https://www.agronomy.org/publications/aj/pdfs/57/5/AJ0570050455 http://dx.doi.org/10.2134/agronj1965.00021962005700050014x

[17] Silveira, P.S. (2010) Época de semeadura e densidade de plantas em cultivares de amendoim no Recôncavo Sul Baiano. Dissertação mestrado, Universidade federal do recôncavo da Bahia, Cruz das Almas, 112.

[18] Silva, M.B. and Beltrão, N.E.M. (2000) Níveis populacionais e configurações de semeadura na cultura do amendoim, em regime de sequeiro na Mesorregião do agreste da Borborema do Estado da Paraíba. Revista de Oleaginosas e Fibrosas, 4, 23-34.

[19] Santos, C.E.R.S., Etamfort, M.P., Freitas, A.D.S., Vieira, I.M.M.B., Souto, S.M., Neves, M.C.P. and Rumjanek, N.G. (2005) Efetividade de rizóbios isolados de solos da região Nordeste do Brasil na fixação do N2 em amendoim (Arachis hypogaea L.). Acta Scientiarum: Biological Sciences, 27, 301-307. http://periodicos.uem.br/ojs/index.php/ActaSciAgron/article/view/1849

[20] Castro, S., Permigiani, M., Vinocur, M. and Fabra, A. (2005) Nodulation in Peanut (Arachis hypogaea L.) Roots in the Presence of Native and Inoculated Rhizobia Strains. Applied Soil Ecology, 13, 39-44.

www.researchgate.net/...Nodulation in peanut http://dx.doi.org/10.1016/S0929-1393(99)00016-5

[21] Borém, A. (2005) Melhoramento de espécies cultivadas. UFV, Viçosa, 525.

[22] Bolonhezi, D., Godoy, I.J. and Santos, R.C. (2005) Melhoramento cultural do amendoim. In: Santos, R.C., Ed., O 
Agronegócio do Amendoim no Brasil, EMBRAPA Algodão, Paraíba, 123-192.

[23] Montans, F.M., Costa, A.F., Guimarães, A.M. and Oliveira, P.S.R. (2008) Aplicação de inoculante, cobalto e molibdênio em amendoim cultivado em solos de diferentes texturas. Unimar Ciências, 17, 21-28. http://www.unimar.br/publicacoes/2009/unimar_ciencias17.pdf

[24] Soares, M.B.B., Finoto, E.L. and Martins, A.L.M. (2011) Produtividade e eficiencia do uso da terra no consórcio entre mandioca e amendoim. Pesquisa \& Tecnologia, 8.

http://www2.aptaregional.sp.gov.br/images_editor/72.MariaBeatriz_ConsorcioMandiocaAmendoim.pdf 